\title{
THE SPECIFICITY
}

$\mathrm{OF}$

\section{SEROLOGICAL REACTIONS}


LONDON : GEOFFREY CUMBERLEGE OXFORD UNIVERSITY PRESS 


\title{
THE SPECIFICITY OF SEROLOGICAL REACTIONS
}

\author{
Revised Edition
}

\author{
BY \\ KARL LANDSTEINER, M.D. \\ The Rockefeller Institute for Medical Research, New York
}

With a Chapter on Molecular Structure and Intermolecular Forces by LINUS PAULING

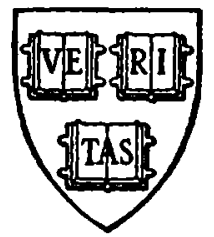

CAMBRIDGE, MASSACHUSETTS HARVARD UNIVERSITY PRESS

1947 
COPYRIGET I936

BY CHARLES C. THOMAS

COPYRIGHT 1945

BY THE PRESIDENT AND FELLOWS OF HARVARD COLLEGE

THIRD PRINTING

PRINTED IN THE UNITED STATES OF AMFRICA 